\title{
Energy Security and the Green Growth Agenda in Africa: Exploring Trade-offs and Synergies
}

\author{
Akinyemi Opeyemi \\ Department of Economics and Development Studies, Covenant University, Ota \\ opeoluwatosin@gmail.com \\ Alege Philip \\ Department of Economics and Development Studies, Covenant University, Ota \\ philip.alege@covenantuniversity.edu.ng \\ Osabuohien Evans \\ Department of Economics and Development Studies, Covenant University, Ota \\ evans.osabuohien@cu.edu.ng \\ Ogundipe Adeyemi \\ Department of Economics and Development Studies, Covenant University, Ota \\ ade.ogundipe@covenantuniversity.edu.ng
}

Doi:10.5901/mjss.2016.v7n1s1p375

\begin{abstract}
The paper examines the effect of the green growth agenda on energy security in Africa using a longitudinal data for the period 1996-2013. The study captures energy security using two basic measures; an aspect sees it as provision of environmentally sustainable energy and alternately in terms of availability/accessibility of energy. Our result shows that the effect of the green growth strategies in ensuring energy security is negligible. On the other hand, consistent with the energy ladder hypothesis, income plays a major influence on energy security in Africa. The study suggests the need to strengthen the institutional arrangement in ensuring the green growth strategies in terms of energy investment and adherence to strict environmental regulation are adequately executed.
\end{abstract}

Keywords: Energy Security, Green Growth, Sustainable Development, Environmental Sustainability, Green Economy.

\section{Introduction}

Sustainable development has been described as development which caters for the present generation without depleting resources for the future generation. A development that is sustainable involves the development of economic and social activities and likewise the protection of the environment in a balanced manner. In other words, development is sustainable when it encompasses economic development, social inclusiveness and environmental sustainability. Any economic growth strategy that will then be "green" must involve these three crucial dimensions. An economy that intends to grow in a sustainable manner must develop a new economic model that will enhance development, alleviates poverty and improve overall quality of life. How best to achieve this is green growth. Green growth essentially seeks to promote efficient utilization of resources, ensure equity and takes the environment into consideration in all production techniques. It represents an attempt at reconciling growth and the environment. If the goal is to protect global environment, raise living standards and ensure reliable energy supplies; green growth is important and inevitable [1].

Current challenges such as climate change have necessitated need for adoption of new paradigm. The impact of climate change is a significant motivation for green growth in Africa [2]. The 2012 African Development Report which was dedicated to assessing Africa's drive towards green growth shows that there is need for African economies to make conscious efforts at developing adequate policy framework in achieving the green growth agenda. This encompasses harnessing the agricultural sector (food security), water and energy sector (phasing out of fossil fuel). As part of efforts at 
making the African continent more productive in the face of socio-economic and environmental challenges, the African Development Bank (AfDB) has placed inclusive growth and transition to green growth at the center of its new 10 year (2013-2022) plan.

In driving this green growth agenda, the energy sector has been identified as a significant player. Energy is an integral component of the growth and development process of any economy [3]. The adequate and reliable supply of energy then becomes essential. Economic systems globally depends on energy supply to fuel all economic activities ranging from transportation, communication, industrial processes, food production, education, health, to security [4]. This establishes the importance of energy. Energy is the "lifeblood" of economies and global economic growth will depend on adequate, affordable and reliable supply of energy [4]. Every economic sector require energy to function properly, thus, the security of energy supply becomes pertinent as fluctuations in supply can hamper economic activity. The achievement of many economic and developmental goals depends on the sustained availability (secure) of different forms of energy [5]. To achieve sustainable development, any country desiring to be in the league of developed economies must have a robust energy base. This energy base must be able to meet both present and future energy needs of the nation [4].

Given the importance of energy, energy security then becomes an important objective to drive a green economy. Energy security defined as the availability of energy resources at an affordable price continues to be a key component of any energy policy in many countries of the world [6]. It is the uninterrupted availability of energy resources at an affordable price [7]. A good energy policy that will produce result must of necessity be able to adequately balance energy security, economic growth and environmental concerns. Many African countries have been making attempts towards designing appropriate policies to address energy security challenges and environmental sustainability. The important role of energy in the economy makes uninterrupted supply a vital issue for all countries today [8].

The threat of global climate change, energy security and human health which poses a challenge to global development, has thus, presented reasons to re-envision developmental approach to innovation and energy technology [9]. This is in view of the fact that the world is experiencing challenges that call for need for adoption of new paradigm. The dual role of the energy sector makes it useful to assess trade-off and synergies in relation to green growth. On one hand, the sector contributes to growth and development. On the other hand, it is one of the contributors to concentration of greenhouse gas in the atmosphere which causes global warming [3].

Most green growth practices create a trade-off. For instance, forest clearing is used to satisfy energy and food needs, at the same time, it is essential for biodiversity. As many developed societies had acknowledged the existence of a direct link between energy availability and economic development [10], there is therefore need for economies to ensure this energy is available in a clean and sustainable manner. The challenge of energy security poses a great threat to a green growth strategy [11], it then becomes imperative to empirically explore the trade-off and synergies between achieving energy security and ensuring "environmental quality-driven growth" in Africa given the demands of many of the development plans of the continent.

\section{Brief Literature Review}

The green economy considered controversial in its definitions as a concept, is classified as a tool for the promotion of sustainable development [12]. The literature on green growth is mostly recent as significant policy debate on the issue had only began since the global financial crisis of 2008 [13]. A converged definition of green growth by the international community consisting of the World Bank, organization of economic cooperation and development (OECD) etc as contained in their several publications, gives a picture of what green growth emphases [2]. It state that green growth is economic growth or job creation that is either compatible with or driven by reduced emissions, improved efficiency in use of natural resources and ecosystem protection. Green growth is described as an approach to economic growth that puts human development at the core while ensuring that natural assets continue to provide the resources and environmental services intended to support sustainable development [14]. It represents an attempt at reconciling environmental and social goals with growth objectives.

Pertaining to Africa, the Green growth concept entails the achievement of critical development objectives while seeking to maximize efficient use of natural resources, minimizing waste and pollution while enhancing resilience of livelihoods [11]. This green growth idea rest upon the need to convert economies from a state of resource-intensity to a low-carbon and resource-efficient level aimed at tackling key challenges such as climate change, energy security, water stress, biodiversity loss, ecosystems decay, among others [15]. Viable solutions to the challenges presented by environmental and socioeconomic changes in Africa calls for a growth pathway that encourages efficient and sustainable management of resources [11]. Thus, this growth strategy will involve low-carbon intensive form. 
In empirical literature, energy security is broad and varies depending on the context and perspective of evaluation and as such, no common definition exists [16]. As a concept, it carries different meanings and interpretations. However, a common denominator in the different definition is that energy security ensures the availability, affordability, reliability and accessibility of energy. The conceptualization energy security follows both the demand and supply standpoint [8]. For supply, net energy importers could view energy security as the diversification of suppliers while on the demand side, net exporters view it as diversification of demand from buyers. Thus, the concept carries different meanings [8]. The renewed interest in the subject of energy security is attributable to the tight oil market and high oil prices of the last decade coupled with threats ranging from terrorism, instability in some exporting countries, geo-political rivalries, fear of scramble for supplies and countries' fundamental need for energy to power growth [17].

Energy security is also the availability of diverse energy resources, sustainable in quantities, affordable in prices, supports economic growth, assists in poverty alleviation, does not harm the environment, and takes into consideration disruptions and shocks [4]. It is a condition where majority of citizens and businesses has access to sufficient energy at affordable rates for the foreseeable future, free from risk of disruptions [8]. There is the existence of a positive relationship between energy security and sustainable development for Nigeria using the elite theory [8]. Future economic growth depends crucially on long-term availability of energy from sources that are affordable, accessible and environmentally harmful [18]. A four-part approach to establishing a green growth agenda for the energy economy includes energy innovation, integration, implementation and transformation [9]. Many have identified possible means to ensure energy security. For instance in Nigeria, such means could include establishing a well-rounded energy mix, proper utilization of gas flared, capacity and infrastructural development, among others. Solely depending on oil and gas as energy source for all sectors is not the best means to ensuring energy security [4]. Even though energy security should encompass availability, accessibility and reliability of the supply of energy, many countries including Nigeria continue to fall short of this description. The Nigerian energy sector is often characterized by unstable fuel supply, price fluctuations, environmental pollution, and so on showing that these challenges have the ability to pose danger to Nigeria's energy security [4].

One of the barriers to clean forms of energy has been identified to be the prevalence of energy subsidies (notable fossil fuel) in many economies. This is due to the fact that they tend to be cheaper compared to the cleaner alternative sources. Thus, they are often at a market disadvantage [9]. The impact of these insecure sources of energy is evident on the environment and health. It involves the exposure to carbon emissions caused by constant use of backyard generators" in different households and businesses [8].

\section{Some Stylized Facts}

Africa's robust economic growth, averaging 5 per cent a year over the past few years, has placed the continent among the fastest growing regions [11]. This growth had been basically driven by increase in commodity prices. Energy will be essential in sustaining this growth; however, this energy would have to be a clean and reliable source. Energy security as an objective will involve making commitment towards a paradigm shift to alternative and environmentally friendly energy that will overall, enhance social welfare and equity.

Currently in Africa, three major sources of fuels exist. They are fossil fuels, biofuels and waste [11]. About 54 per cent represents the share of fossil fuel in total primary energy supply while as at 2010 about 80 per cent of Africa's electricity was supplied from fossil fuel [11]. If Africa must achieve green growth, reform policies are needed. Some of these policies include subsidy reform (fuel), environmental tax, energy efficiency, low carbon investment (renewable energy). Fuel subsidy particularly deteriorates the environment and acts against the fight against climate change [5]. Efforts at promoting green growth make its reform important.

Energy access is an aspect of energy security. Only 42 per cent of population in Africa had access to electricity in 2008 and this is projected to increase to about 66 per cent by 2040 [11]. A large percentage of rural poor in Africa continue to depend on traditional biomass/wood fuel as sources of energy. In achieving developmental objectives, growing demand for energy must be met, but with cleaner, affordable, reliable and cleaner energy. The continued use of biomass and wood fuel to meet this growing energy needs will threaten the prospect of green growth.

\section{Analytical Framework}

The section presents the analytical framework of the connection between energy security and green growth within the context of sustainable development. Figure 1 presents the framework of green growth and energy security. It shows that sustainable development comprises of three components namely economic development, social inclusiveness and 
environmental sustainability. In driving towards a green growth, environmental sustainability will be a key consideration in enhancing economic growth and development within a society that promotes equity. Likewise, for green growth to be achievable, it will employ a number of policy instruments such as subsidy reform (e.g. fossil fuel), environmental (carbon or energy) tax, energy efficiency and low carbon development (e.g. renewables). These policies will invariably help to ensure the security of energy supply.

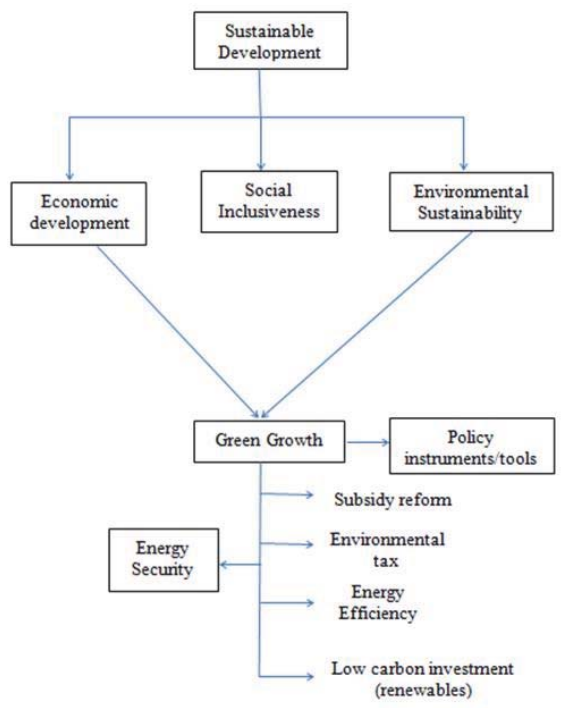

Figure 1: Analytical Framework of Green Growth and Energy Security

Source: Authors'

\section{Methodology}

\subsection{The Model}

Generally, a number of extant studies on energy security adopt descriptive approaches while due non-availability of data studies from Africa are largely limited. The study adopts two basic models, one views energy security from the point of sustainable environment and the second sees it in terms of energy accessibility. The two models developed in this study are presented as follows:

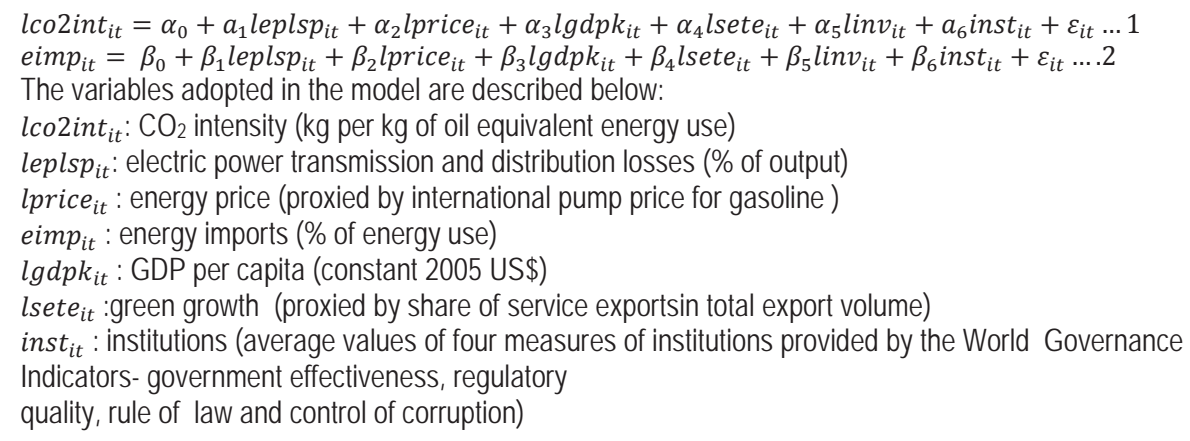

\section{Data Source}

The study used a longitudinal data for the period 1996 to 2013 for thirty-seven Africa countries. The data used for $\mathrm{CO}_{2}$ 
intensity, electric power transmission and distribution losses, energy price, energy imports, GDP per capita and green growth indicators were obtained from the World Development Indicators of the World Bank while data for institutions were obtained from the World Governance Indicators 2013 of the World Bank.

\subsection{Estimation Procedure}

The study adopts a panel data analysis, the estimation exercise is preceded by conducting the multicollinearity test; this examines the possibility of collinear dependence among the explanatory variables adopted in the study. Consequently, the study primarily adopted a dynamic panel data estimation procedure. The choice is premised on the fact that the ordinary least square pooled regression has been criticized in various studies ([19]; [20]) particularly where the lagged dependent variable enters the set of explanatory variables. Likewise, the static regression techniques, though, accounts for country specific heterogeneity and its transformation could provide lags of the variables as instruments implying the consistency of estimates. However, such consistency is not applicable to short panels. In short panels, the static regression eliminates individual heterogeneity but does not account for the issue of persistency of the dependent variable. Thus, regression analysis of our model require a better method of estimation (preferably, the system GMM) in situation where regressors can be endogenous, there is short time dimension in panel and finding a perfect exogenous variable(s) becomes cumbersome (Bond 2002; Buhai 2003).

\section{Discussion of Results}

\subsection{Multicolliearity test}

Table 1 presents the result of multicollinearity test using the pairwise correlation matrix and the variance inflation factor. While the former does not have a standard decision rule on when collinearity becomes a problem, the latter suggests a vif value not more than 5 and tolerance (1/VIF) value not lower than 0.2 . A critical observation shows that the problem of multicollinearity is not inherent in the model which implies that the unique effect of the explanatory variables can be ascertained.

Table 1: Multicollinearity test

\begin{tabular}{|c|c|c|c|c|c|c|}
\hline \multicolumn{7}{|c|}{ Pairwise correlation matrix } \\
\hline variable & lep/sp & lgdpk & Iprice & Isete & $\operatorname{linv}$ & inst \\
\hline lep/sp & 1.0000 & & & & & \\
\hline lgdpk & 0.1332 & 1.0000 & & & & \\
\hline Iprice & 0.0147 & -0.1389 & 1.0000 & & & \\
\hline Isete & -0.1701 & -0.2699 & 0.4629 & 1.0000 & & \\
\hline linv & 0.0988 & 0.0294 & -0.1503 & -0.0955 & 1.0000 & \\
\hline inst & 0.0157 & 0.4292 & 0.1412 & 0.3669 & -0.1154 & 1.0000 \\
\hline \multicolumn{7}{|c|}{ Variance Inflation Factor } \\
\hline & VIF & $1 / \mathrm{NIF}$ & & & & \\
\hline lep/sp & 2.52 & 0.3976 & & & & \\
\hline lgdpk & 2.40 & 0.4172 & & & & \\
\hline Iprice & 2.21 & 0.4531 & & & & \\
\hline Isete & 1.17 & 0.8536 & & & & \\
\hline $\operatorname{linv}$ & 1.14 & 0.8745 & & & & \\
\hline inst & 1.10 & 0.9128 & & & & \\
\hline Mean VIF & 1.75 & & & & & \\
\hline
\end{tabular}

Source: Computed using Stata 11.0

Table 1.2 presents the regression result for model one. The first model observes energy security in terms of environmental sustainability. Here, carbon dioxide intensity of energy use is adopted in capturing energy security. The OLS and the static panel regression show that energy security is more responsive to GDP per capita, causing about 98 percent, 24 percent and 48 percent in the OLS, fixed effect and random effect regressions respectively. Since the focus of our estimation procedure is based on the dynamic regression, we proceed to intercept the GMM result. Here, all the 
explanatory variables were significant in explaining energy security. Similar to the evidence obtained using the static regression, GDP per capita exerts the highest variation on energy security. This implies that income determines the choice of energy sources used; this is consistent with the energy ladder hypothesis where income is seen as a primary factor for adopting cleaner energy sources. The estimated result show that a percent change in GDP per capita causes about 42.5 percent change in energy security. Also, electric power transmission and distribution losses, and energy price exert about 3.0 percent and 3.3 percent respectively to energy security.

The indicator of green growth becomes significant at 10 percent significance level and contributes about 1.0 percent to variations in energy security. The weak significance and magnitude might not be unconnected to the fact that most Africa economies has not really translated into the less carbon economy. Consequently, the level of institutions contributes significantly to energy security. A percent change in institutions brings about 16.5 percent changes in energy security. Generally, institutional qualities are weak in Africa, corruption is endemic and government is partially absent which creates a vast impediment for sustainable development; a restructure of Africa's institutional arrangement for transparency and effectiveness will enhance provision of environmental abatement measures and ensure sustainable energy development. Lastly, energy security weakly respond to energy investment, a percent change in investment culminates into a mere 0.23 percent change in energy security. This implies that energy investment is grossly inadequate; investment targeted towards provision of cleaner energy sources and off-grid energy provision to rural communities tends to reduce heavy reliance on traditional biomass and enhances sustainable environmental development.

Table 2: Regression Results: Model One

\begin{tabular}{|c|c|c|c|c|}
\hline & \multirow[t]{2}{*}{ OLS } & \multicolumn{2}{|c|}{ Static panel regression } & \multirow{2}{*}{$\begin{array}{c}\text { Dynamic panel regression } \\
\text { GMM }\end{array}$} \\
\hline & & Fixed effect & Random effect & \\
\hline VARIABLES & Ico2int & Ico2int & Ico2int & Ico2int \\
\hline L.Ico2int & & & & $\begin{array}{l}-0.105 \\
(0.145)\end{array}$ \\
\hline leplsp & $\begin{array}{c}0.0478 \\
(0.0383)\end{array}$ & $\begin{array}{c}-0.0541^{\star *} \\
(0.0237)\end{array}$ & $\begin{array}{l}-0.0458^{*} \\
(0.0242)\end{array}$ & $\begin{array}{c}0.0298^{*} \\
(0.0175)\end{array}$ \\
\hline Iprice & $\begin{array}{l}-0.385^{* \star \star} \\
(0.0493)\end{array}$ & $\begin{array}{c}0.0286 \\
(0.0451)\end{array}$ & $\begin{array}{c}-0.0621 \\
(0.0393)\end{array}$ & $\begin{array}{l}0.0329^{* *} \\
(0.0165)\end{array}$ \\
\hline lgdpk & $\begin{array}{l}0.983^{* * *} \\
(0.0383)\end{array}$ & $\begin{array}{c}0.243^{\star *} \\
(0.0966)\end{array}$ & $\begin{array}{l}0.475^{\star * *} \\
(0.0766)\end{array}$ & $\begin{array}{l}0.425^{* * *} \\
(0.126)\end{array}$ \\
\hline Isete & $\begin{array}{l}0.369^{\star \star \star} \\
(0.0350)\end{array}$ & $\begin{array}{l}0.0796^{\star *} \\
(0.0382)\end{array}$ & $\begin{array}{l}0.0917^{* *} \\
(0.0376)\end{array}$ & $\begin{array}{l}0.0107^{*} \\
(0.0122)\end{array}$ \\
\hline linv & $\begin{array}{c}0.0621^{\star \star *} \\
(0.0139)\end{array}$ & $\begin{array}{l}-0.0168 \\
(0.0107)\end{array}$ & $\begin{array}{l}-0.0126 \\
(0.0108)\end{array}$ & $\begin{array}{l}-0.00225^{*} \\
(0.00290)\end{array}$ \\
\hline inst & $\begin{array}{l}-0.351^{* \star \star} \\
(0.0721)\end{array}$ & $\begin{array}{c}0.0382 \\
(0.0942)\end{array}$ & $\begin{array}{l}0.00483 \\
(0.0901)\end{array}$ & $\begin{array}{l}0.165^{\star * \star} \\
(0.0602)\end{array}$ \\
\hline Constant & $\begin{array}{c}-7.720 * \star \\
(0.332)\end{array}$ & $\begin{array}{l}-1.020 \\
(0.746)\end{array}$ & $\begin{array}{c}-2.810^{\star * \star} \\
(0.616)\end{array}$ & $\begin{array}{c}-2.875^{\star \star \star} \\
(0.947)\end{array}$ \\
\hline $\begin{array}{l}\text { Observations } \\
\text { R-squared }\end{array}$ & $\begin{array}{c}252 \\
0.816\end{array}$ & $\begin{array}{l}251 \\
0.153\end{array}$ & 251 & 176 \\
\hline Number of id & & 20 & 20 & 19 \\
\hline F-test (wald ${ }^{2}$ ) & - & & - & 58901.56 \\
\hline F-test (p-values) & 0.0000 & 0.0000 & 0.0000 & 0.0000 \\
\hline Sargan & - & - & - & 0.9009 \\
\hline Hansen & - & - & - & - \\
\hline$A R(1)$ & - & - & - & 0.0507 \\
\hline$A R(2)$ & - & - & - & 0.0287 \\
\hline No. of instruments & - & - & - & 17 \\
\hline
\end{tabular}

Source: computed using Stata 11.0

Table 2 present the regression estimates for model two. Here, energy security is addressed in terms of energy access using the proportion of energy imports in total energy use. The result obtained are quite similar to evidences from model one. All the estimation techniques attempted show that GDP per capita is highly significant and poses the largest negative influence on energy security. This implies that as income increases, energy import diminishes and energy 
access is improved because consumption will be weakly susceptible to external shocks. The GMM results show that a percent change in electric power transmission and distribution losses leads to about 15 unit reduction in energy imports, whereas, a percent change in GDP per capita leads to about 78.2 unit reduction in energy imports. Also, the indicator of green growth exerts a significant influence on energy imports, the study shows that as green growth strategy improves, energy import increases. This is not unlikely as the present growth process in Africa is dirty induced. Africa economies still rely heavily on export of one or two primary commodities for its major foreign earnings and its non-dirty sectors are just evolving. Also as witnessed in model one, energy investment weakly influences the outcomes in energy security, as only 1.7 unit dynamism in energy security is attributable to a percent change in energy investment. Lastly, asides GDP per capita, institutions exert the strongest variation on energy security. A sound institutional arrangement where rule of law is respected, elitist capture is minimized and bureaucratic bottlenecks are checked can promptly deliver sustainable agenda.

Table 3: Regression Results: Model two

\begin{tabular}{|c|c|c|c|c|}
\hline & \multirow[t]{2}{*}{$O L S$} & \multicolumn{2}{|c|}{ Static Panel Regression } & \multirow{2}{*}{$\frac{\text { Dynamic Regression }}{\text { (GMM) }}$} \\
\hline & & Fixed effect & Random effect & \\
\hline VARIABLES & eimp & eimp & eimp & eimp \\
\hline l.eimp & & & & $\begin{array}{c}0.521^{\star \star \star} \\
(0.000844)\end{array}$ \\
\hline leplsp & $\begin{array}{c}-96.24^{\star \star *} \\
(20.15)\end{array}$ & $\begin{array}{l}0.0293 \\
(11.58)\end{array}$ & $\begin{array}{l}-0.870 \\
(11.73)\end{array}$ & $\begin{array}{c}-15.07^{\star \star \star} \\
(1.550)\end{array}$ \\
\hline lgdpk & $\begin{array}{c}-142.7^{* \star *} \\
(20.48)\end{array}$ & $\begin{array}{l}-64.61 \\
(46.09)\end{array}$ & $\begin{array}{c}-99.92^{* * *} \\
(37.46)\end{array}$ & $\begin{array}{c}-78.20^{\star \star \star} \\
(4.951)\end{array}$ \\
\hline Iprice & $\begin{array}{l}24.97 \\
(26.04)\end{array}$ & $\begin{array}{l}39.51^{*} \\
(21.10)\end{array}$ & $\begin{array}{l}54.71^{* \star *} \\
(18.64)\end{array}$ & $\begin{array}{l}12.69^{\star \star \star} \\
(1.846)\end{array}$ \\
\hline Isete & $\begin{array}{c}52.78^{\star \star *} \\
(18.92)\end{array}$ & $\begin{array}{l}-8.045 \\
(18.67)\end{array}$ & $\begin{array}{c}7.043 \\
(18.34)\end{array}$ & $\begin{array}{c}15.61^{\star \star *} \\
(0.686)\end{array}$ \\
\hline linv & $\begin{array}{l}-7.360 \\
(7.139)\end{array}$ & $\begin{array}{c}0.860 \\
(4.336)\end{array}$ & $\begin{array}{l}0.0484 \\
(4.389)\end{array}$ & $\begin{array}{l}1.712^{\star \star \star} \\
(0.328)\end{array}$ \\
\hline inst & $\begin{array}{c}348.9^{\star * \star} \\
(38.27)\end{array}$ & $\begin{array}{l}15.94 \\
(44.29)\end{array}$ & $\begin{array}{c}68.07 \\
(42.57)\end{array}$ & $\begin{array}{l}-15.87^{* * *} \\
(3.000)\end{array}$ \\
\hline Constant & $\begin{array}{l}1,571^{\star \star *} \\
(177.0)\end{array}$ & $\begin{array}{c}329.5 \\
(353.0)\end{array}$ & $\begin{array}{l}629.7^{* *} \\
(297.6)\end{array}$ & $\begin{array}{c}551.5^{\star \star *} \\
(44.70)\end{array}$ \\
\hline $\begin{array}{c}\text { Observations } \\
R \text {-squared }\end{array}$ & $\begin{array}{l}268 \\
0.568\end{array}$ & $\begin{array}{l}267 \\
0.016\end{array}$ & 267 & 188 \\
\hline Number of id & & 21 & 21 & 20 \\
\hline $\begin{array}{c}\left.\text { F-test (wald }{ }^{2}\right) \\
\text { F-test (p-values) }\end{array}$ & 0.0000 & $0 . \overline{0}$ & $\begin{array}{l}0.089 \\
0.0000\end{array}$ & $\begin{array}{c}5689.67 \\
0.0000\end{array}$ \\
\hline Sargan & - & - & - & 0.7072 \\
\hline Hansen & - & - & - & - \\
\hline$A R(1)$ & - & - & - & 0.0081 \\
\hline$A R(2)$ & - & - & - & 0.0413 \\
\hline No. of instruments & - & - & - & 17 \\
\hline
\end{tabular}

Source: Computed using Stata 11.0

\section{Conclusion and Recommendation}

The study examines the impact of green growth agenda on energy security in Africa using a longitudinal data for the period 1996-2013. The study captures energy security in two dimension; an aspect views energy security in terms of provision of environmentally sustainable energy. Alternatively, energy security is observed via its accessibility. The study primarily adopted the generalized method of moments due to some inherent challenges associated with the OLS and the static panel regression techniques. The estimated result readily available in table 2 and 3 shows that the indicators of green growth weakly influence changes in energy security. This can be attributed to the fact that the non-dirty industry has not fully evolve in Africa, majority of Africa's exports are domiciled in the extractive industry (largely commodities) with low environmental abatement technologies. 
To put succinctly, the present growth processes are concentrated in the extractive sectors and low-skill manufacturing where adherence to strict environment regulation is conspicuously absent which progressively increases the level of dirty induced growth in Africa.

Consequently, the study found that GDP per capita plays critical role in ensuring energy security, consistent with the energy ladder hypothesis, income represents a major determinant in accessing cleaner energy sources. Conversely, the effect of energy investment on energy security appears negligible. This evidence would have been accentuated by the weak institutions in Africa; though the quality of institutions tends to play a major role in ensuring sustainable and quality energy sources. Hence, there is need to build stronger institutional arrangement to ensure energy funding are adequately initiated and appropriately channeled, this will help to ensure elitist capture of economic resources are minimized and contracts are adequately executed.

\section{References}

Organisation for Economic Co-operation and Development (OECD). OECD Green Growth Studies: Energy. OECD, 2011.

African Development Bank-ADB, Facilitating green growth in Africa: Perspective from the African Development Bank. Discussion Paper. June 2013

O. Akinyemi, A. Ogundipe and P. Alege. "Energy Supply and Climate Change in Nigeria". Journal of Environment and Earth Science. Vol. 4, No. 14. Pp. 47-61. 2014. ISSN (online):2225-0948.

M. Borok, A. J. Agandu, and M. M. Morgan, "Energy security in Nigeria: Challenges and way forward," International Journal of Engineers Science Invention Japan, vol. 2, issue 11 pp. 1-6, 2013. ISSN (online):2319-6734

O. Akinyemi, P. Alege, O. Ajayi, L. Amaghionyediwe and A. Ogundipe. "Fuel Subsidy Reform and Environmental Quality in Nigeria". International Journal of Energy Economics and Policy. Unpublished. 2015.

C. Winzer, Conceptualizing Energy Security. Cambridge Working Paper in Economics 1151 \& EPRG Working Paper 1123.

International Energy Agency-IEA, "Energy Supply Security: Emergency Response of IEA Countries" OECD/IEA. 2014.

R. C. Okeke, E. M. C. Izueke, and F. I. Nzekwe, "Energy Security and Sustainable Development in Nigeria." Arabian Journal of Business and Management Review (OMAN Chapter). vol.4, no 3, in press. October 2014.

N. Hultman, K. Sierra, and G. Carlock, "Energy and green growth: Recasting the Options, re-envisioning sustainability," Paper prepared as an input to the Club of Madrid September 2011 workshop titled "The G-20 in a Post-Crisis World".

P. Llyod, "Energy security and development," Paper delivered at UNEP Workshop on "Energy Access" Cape town, South Africa.

Africa Development Report, "Towards green growth in Africa. African Development Bank (AfDB) Group. 2012. ISBN 978-9938-882-001.

United Nations Economic Commission for Africa, "Study on Green Economy in West Africa: Capacity building of West African countries in the green economy for climate change mitigation". West African Sub-regional Office. 2013

A. Scott, W. McFarland and P. Seth, "Research and evidence on green growth", Report produced by Overseas Development Institute for Evidence on Demand. July 2013. doi:http://dx.doi.ord/10.12774/eod hd064.july2013.scott

OECD, "Green Growth Newsletter" Green Growth Strategy, Issue 2. November 2013.

G. Nhamo, "Green growth: A game changer ushering in the death of the internal combustion engine," WIT Transactions on Ecology and the Environment, vol. 186, WIT Press. ISSN 1743-3541 (online). doi: 10.2495/ESUS140051.

M. I. Bazilian, B. Sovacool, and M. Miller, "Linking energy independence to energy security," International Association for Energy Economics, IAEE USA, Third Quarter 2013.

D. Yergin, "Ensuring Energy Security". Foreign Affairs, 85(2). 2006, pp.69-82.

S. A. Oyedepo, "On energy for sustainable development in Nigeria". Renewable and Sustainable Energy Reviews 16. 2012, pp.25832598.

P. O. Alege and A. A. Ogundipe, "Foreign Direct Investment and Economic Growth in ECOWAS: A System GMM Approach". Covenant Journal of Business and Social Sciences vol. 5 no. 2

A. A. Ogundipe, P. Ojeaga and O. M. Ogundipe, "Is Aid Really Dead? Evidence from Sub-Saharan Africa". International Journal of Humanities and Social Science vol. 4 no. 10. 